\title{
ДІАГНОСТИЧНА ТА ПРОГНОСТИЧНА ЦІННІСТЬ ЗАПАЛЬНИХ ПАТТЕРНІВ КРОВІ ДЛЯ ВИБОРУ ІНДИВІДУАЛІЗОВАНОГО ЛІКУВАННЯ БРОНХІАЛЬНОЇ АСТМИ В ДІТЕЙ
}

\author{
Тарнавська С. І., Шахова О. О.
}

\section{ВСТУП}

Бронхіальна астма (БА) належить до числа найбільш поширених хронічних захворювань дитячого віку, які значною мірою формують захворюваність, розповсюдженість патології та інвалідність дітей ${ }^{1}$.

Незважаючи на те, що лише 5-10\% паціснтам притаманне тяжке персистування захворювання ${ }^{2}$, близько $55 \%$ хворих мають його неконтрольований перебіг ${ }^{3}$. Слід визнати, що, попри досягнуті успіхи в лікуванні бронхіальної астми, за допомогою стандартної протизапальної терапії не завжди вдається втримати контроль над захворюванням ${ }^{4}$, а згідно 3 наявними вітчизняними та міжнародними стандартами і протоколами діагностики й терапії можливість досягти контролю не перевищує $60 \%$ випадків $^{5}$. Певною мірою це пов'язане 3 фенотиповою неоднорідністю бронхіальної астми в дітей, що зумовлює необхідність розширення кола наукових пошуків щодоверифікації різних запальних фенотипів хвороби.

Виходячи з наведеного вище, численні мультицентрові дослідження продемонстрували зростання інтересу науковців до верифікації запальних фенотипів бронхіальної астми. Особлива увага акцентувалася на тому, що лише кожен другий випадок астми пов'язаний is еозинофільним характером запалення дихальних шляхів (ДШ $)^{6}$.

\footnotetext{
${ }^{1}$ Backer V., Stensen L., Sverrild A., et al. Objective confirmation of asthma diagnosis improves medication adherence. J Asthma. 2018. Vol. 55(11). P. 1262-1268.

2 Benedictis D., Bush A. Asthma in adolescence: Is there any news? Pediatrics Pulmonology. 2017. Vol. 52(1). P. 129-138.

${ }^{3}$ Borak1 J., Lefkowitz R.Y. Bronchial hyperresponsiveness. Occupational Medicine. 2016. Vol. 66. P. 95-105.

${ }^{4}$ Castro-Rodriguez J. A. The Asthma Predictive Index: early diagnosis of asthma. Curr Opin Allergy Clin Immunol. 2011. Vol. 11(3). P. 157-61.

${ }^{5}$ Chen Q., Zhong X., Acosta L., et al. Allergic sensitization patterns identified through latent class analysis among children with and without asthma. Ann Allergy Asthma Immunol. 2016. Vol. 116(3). P. 212-8.

${ }^{6}$ Cockcroft D.W. Methacholine challenge. PD20 versus PC20. Ann Am Thorac Soc. 2015. Vol. 12. P. 291-292.
} 
Iз впровадженням у практику цитологічного дослідження харкотиння для визначення співвідношення клітин запальної відповіді 3'явився новий напрямок у фенотипуванні бронхіальної астми, а саме за характером запальної реакції бронхів. Пропонувався розподіл на еозинофільний, нейтрофільний, пойкілоцитарний (iз нормальним співвідношенням клітинних елементів) та змішаний (iз підвищенням вмісту нейтрофільних та еозинофільних гранулоцитів) фенотипи захворювання ${ }^{7}$ як за даними цитологічного дослідження харкотиння, так і за показниками вмісту гранулоцитів у мазках периферичної крові. Найбільшого визнання фахівців набув розподіл на еозинофільний та нееозинофільний/нейтрофільний варіанти запалення дихальних шляхів, що асоціюють із відповідними фенотипами бронхіальної астми 8

Відносно довгий час науковцями підтримувалась Тh2-гіпотеза як основа патогенезу бронхіальної астми, яка пояснювала розвиток IgEзалежної сенсибілізації за активної участі Th2-субпопуляцій CD4+лімфоцитів із наступним формуванням опосередкованого IL-5 еозинофільного запалення ДШ, що спричиняло підвищення бронхіальної реактивності і як наслідок - обструкції дихальних шляхів ${ }^{9}$.

Перші контраргументи виникли у дослідників, які отримали позитивний ефект від протизапальної терапії у пацієнтів із еозинофілією харкотиння та відсутністю гіперреактивності ДШ ${ }^{10}$. Окрім того, Turner та співавтори повідомляли про перебіг БА у хворих, в яких мали місце клінічні симптоми захворювання, був присутній позитивний ефект від застосування $\beta 2$-агоністів, мала місце виразна гіперреактивність ДШ, але за нормального вмісту еозинофілів у харкотинні. Наведені дані ставили під сумнів Тh2-гіпотезу БА та припускали наявність іншого, нееозинофільного іiі фенотипу.

Найбільш дискусійним виявилося питання відносно узгодження термінів «еозинофільна» (за типом запальної відповіді бронхів) i «атопічна/алергічна» (за механізмом) бронхіальна астма, та «нееозинофільна/нейтрофільна» астма i неатопічна/неалергічна ${ }^{11}$.

${ }^{7}$ Coşkun O., Ercan N., Bostanci I. Peripheral blood inflammatory patterns in the control levels of asthma in children. J Asthma. 2019. Vol. 5. P. 1-15.

${ }^{8}$ Durrant M.D., Metzger D.W. Emerging roles of T helper subsets in the pathogenesis of asthma”Immunological Investigations. 2010. Vol. 39(4-5). P. 526-549.

9 Gibson P. Inflammatory phenotypes in adult asthma: clinical applications. The Clinical Respiratory Journal. 2009. Vol. 3. P.198-206.

${ }^{10}$ Hastie A.T., Steele C., Dunaway C.W., et al. Complex association patterns for inflammatory mediators in induced sputum from subjects with asthma. Clin Exp Allergy. 2018. Vol. (7). P. 787-797.

${ }^{11}$ Helen K. Reddel, J. Mark Fitz Gerald, Eric D. Bateman GINA 2019: a fundamental change in asthma management . European Respiratory Journal. 2019. Vol. 53(6). P. 1901-1946. 
Наявність позитивних шкірних прік-тестів, надмірна концентрація у сироватці крові специфічних IgE, еозинофілія периферичної крові та/або індукованого мокротиння, як правило, притаманні хворим на еозинофільну БА. Проте у ряді досліджень $\epsilon$ повідомлення про наявність інтенсивного еозинофіл-опосередкованого запалення ДШ у дітей, хворих на неатопічну БА.

Більшість авторів наразі схильні поділяти БА на еозинофільну та неозинофільну/нейтрофільну з огляду на дані цитологічного складу бронхіального секрету ${ }^{12}$, або за показниками периферичної крові ${ }^{13}$, не утотожнюючи при цьому отримані дані 3 наявністю/відсутністю ознак атопії у пацієнтів.

Накопичені останніми роками дані наукової літератури щодо асоціації тяжкості перебігу захворювання з певним запальним фенотипом БА переважно є доволі суперечливими. Так, окремі автори вказують на переважно нейтрофільну модель астми за тяжкого перебігу хвороби, інші - на виразну гіперчутливість ДШ та, відповідно, тяжчий перебіг захворювання за наявності еозинофільного характеру запалення бронхів ${ }^{14}$.

Водночас, акцентуючи увагу на запальних фенотипах крові, окремі автори встановили, що еозинофілія крові трапляється у 58,6\% дітей, хворих на БА. За даними інших дослідників, кількість еозинофілів у периферичній крові при БА $є$ досить динамічним показником, який змінюється залежно від температурної реакції, наявності інфекції, періоду захворювання, характеру лікування, і навіть періоду доби. Зокрема, застосування глюкокортикоїдів, $\beta_{2}$-агоністів, теофілінів та кромонів знижує кількість еозинофілів та їхніх продуктів у крові. Збільшення кількості еозинофільних гранулоцитів у периферичній крові переважно пояснюють міграцією клітин із шокових органів у кров по завершенню гострого періоду хвороби ${ }^{15}$.

Водночас існування інших, нееозинофільних запальних механізмів розвитку бронхіальної астми непрямо підтверджують дослідження щодо часткової ефективності лікування БА за допомогою антитіл, які нейтралізують $\operatorname{IgE}$ (анти-IgE) та застосування анти-інтерлейкін - 5 терапії.

${ }^{12}$ Kooijman M.N., van Meel E.R., Steegers E., et al. Fetal umbilical, cerebral and pulmonary blood flow patterns in relation to lung function and asthma in childhood. Pediatr Allergy Immunol. 2019. Vol. 30(4). P. 443-450.

${ }^{13}$ Kim S., Lee C.H., Jin K.N., Cho S.H., Kang H.R. Severe asthma phenotypes classified by site of airway involvement and remodeling via chest CT scan. J Investig Allergol Clin Immunol. 2018. Vol. 28(5). P. 312-320.

${ }^{14}$ Nadif R., Siroux V., Boudier A., et al. Blood granulocyte patterns as predictors of asthma phenotypes in adults from the EGEA study. Eur Respir J. 2016. Vol. 48(4). P. 1040-1051.

${ }^{15}$ Ortega H., Llanos J.P., Lafeuille M.H., et al. Effects of systemic corticosteroids on blood eosinophil counts in asthma: real-world data. J Asthma. 2019. Vol. 56(8). P. 808-815. 
Показано, що нейтрофіли активно залучаються до запального процесу у хворих на БА, проте це не свідчить про інфекційну природу запалення ${ }^{16}$.

Хоча наразі остаточно ще не з'ясовані механізми реалізації нейтрофільного варіанту запалення бронхів при БА, вважається, що його розвиток відбувається внаслідок активації Th1-лімфоцитів у дихальних шляхах. При цьому тригерними чинниками реалізації нейтрофільного фенотипу БА найчастіше $\epsilon$ зовнішні чинники: ірританти, вплив тютюнового диму, ендотоксинів, бактеріальних та вірусних ДНК та РНК, а також грибки, що розпізнаються такими компонентами імунної системи, як Тоll-подібні рецептори, CD14 та протеїни легеневого сурфактанту. Це призводить до активації ядерного фактору кВ (NF-кB) та подальшої продукції первинно активованими клітинами бронхіального дерева (макрофагами та моноцитами) прозапальних цитокінів (tumour necrosis factor $\alpha$ (TNF $\alpha$ ), інтерферон- $\gamma$ (INF- $\gamma$ ), IL 6, 8, 10, 12). При цьому зазначені цитокіни активують міграцію нейтрофілів, лімфоцитів та моноцитів у дихальні шляхи, стимулюють продукцію IgG. Основним хемокіном нееозинофільного запалення наразі вважають IL-8, який не лише підвищує рекрутизацію нейтрофілів, сприяє їх міграції та інфільтрації ними стінки бронхів, але й потенціює вихід із гранулоцитів потужних прозапальних цитотоксичних речовин, зокрема мієлопероксидази і катіонних білків, що спричиняють пошкодження тканин, та лейкотрієну В4, який підвищує реактивність дихальних шляхів.

Формування нейтрофільного фенотипу БА можна представити таким чином: змінені бронхи колонізує непатогенна мікрофлора переважно за рахунок зниження місцевого захисту (у хворих виявляється дефіцит макрофагів в індукованому мокротинні та в імунограмі), внаслідок чого прогресує нейтрофільне запалення, і токсичні речовини, що виділяються нейтрофілами, призводять до дестабілізації опасистих клітин ${ }^{17}$.

Водночас кореляції між маркерами запалення - еозинофілами та нейтрофілами в індукованому харкотинні, та вмістом даних гранулоцитів у периферичній крові мало вивчені, проте відомо, що морфофункціональні характеристики еозинофілів бронхів та крові збігаються ${ }^{18}$. Установлено, що вміст еозинофілів та нейтрофілів у дихальних шляхах та крові залежить від впливу чинників зовнішнього середовища, врахування яких дасть можливість скласти план індивідуальних профілактичних заходів хворим на БА.

${ }^{16}$ Persson C. Primary lysis of eosinophils in severe desquamative asthma Clin. Exper. Allergy. 2014.Vol. 44(2). P. 173-183.

${ }^{17}$ Pirogov A.B., Gassan D.A., Zinov'ev S.S., et al. Destruction of the bronchial epithelium in patients with severe asthma according to different patterns of inflammation and cold airway hyperresponsiveness. Ter Arkh. 2019. Vol. 91(3). P. 31-35.

${ }^{18}$ Rakowski E., Zhao S., Liu M., et al. Variability of blood eosinophils in patients in a clinic for severe asthma. Clin Exp Allergy. 2019. Vol. 49(2). P. 163-170. 
У клінічний практиці більш доступним методом $\epsilon$ визначення запальних фенотипів за вмістом циркулюючих гранулоцитів у периферичній крові. Так, ряд авторів вказують на існування чотирьох запальних фенотипів бронхіальної астми за вмістом циркулюючих у крові еозинофілів та нейтрофілів: гіпогранулоцитарний, або пауцигранулоцитарний (із нормальним вмістом вказаних гранулоцитів), еозинофільний (за наявності еозинофілії крові понад 250 кл/мм ${ }^{3}$ ), нейтрофільний (за наявності нейтрофілів крові понад 5000кл/мм ${ }^{3}$ ) та гіпергранулоцитарний (із підвищеним вмістом еозинофільних та нейтрофільних гранулоцитів крові).

Окремі дослідники пов'язують почастішання нічних симптомів хвороби, тяжкий перебіг захворювання, який потребує застосування високих доз інгаляційних глюкокортикостероїдів, саме із гіпергранулоцитарним запальним паттерном крові в дітей, хворих на бронхіальну астму. Призначення високих доз ІГКС таким пацієнтам, 3 одного боку, призводить до апоптозу еозинофілів, з іншого - подовжує життя нейтрофільних гранулоцитів крові, спричиняючи більш тяжкий перебіг захворювання. Висока еозинофілія та нейтрофілія в дітей, хворих на БА може бути пов'язана із впливом чинників зовнішнього середовища, наприклад 3 озоном, який за останніми даними $\epsilon$ промотором антиапоптозних чинників довкілля у алергенсенсибілізованих тварин ${ }^{19}$.

Еозинофільному запальному фенотипові БА (за показниками вмісту гранулоцитів у периферичній крові) притаманні позитивні шкірні тести із стандартними алергенами, підвищення вмісту специфічних $\operatorname{IgE}$ у крові, еозинофілія крові, зниження об'єму форсованого видиху за 1 секунду (ОФВ1). Нейтрофільна модель БА характеризується тяжчим перебігом захворювання, втримати контроль над яким досить складно за допомогою протизапальної терапії, менш виразною алергічною сенсибілізацією, помірно вираженими результатами шкірних тестів 3 алергенами, фіксованою обструкцією ДШ. Для пацієнтів з нейтрофільним фенотипом характерним $\epsilon$ помірна реакція на бронхолітичну терапію та низькі показники ОФВ1 після застосування бронходилятаторів.

\section{1. Клінічні особливості перебігу бронхіальної астми} в дітей шкільного віку за різних паттернів запалення крові

Нами проведено комплексне клінічно-імунологічне обстеження I-II рівня 120 дітей, хворих на бронхіальну астму. Залежно від вмісту гранулоцитів крові сформовані чотири клінічні групи. Першу (I) групу

${ }^{19}$ Teague W.G., Lawrence M.G., Shirley D.T., et al. Lung lavage granulocyte patterns and clinical phenotypes in children with severe, therapy-resistant asthma. J Allergy Clin Immunol Pract. 2019. Vol. 7(6). P. 1803-1812. 
становили 34 дитини, які хворіють на БА із гіпогранулоцитарним патерном запалення (вміст еозинофілів крові $<250$ клітин $/ \mathrm{Mм}^{3}$ та нейтрофілів $<5000$ клітин/мм ${ }^{3}$ ) (середній вік - 13,7 $\pm 2,6$ року, частка хлопчиків - 64,7\%), до II групи увійшли 60 дітей, хворих на БА 3 переважно еозинофільним патерном периферичної крові (вміст еозинофілів $\geq 250$ клітин/мм ${ }^{3}$ ) (середній вік - 12,8 $\pm 2,9$ року, частка хлопчиків - 70,0\%), до III групи увійшли 14 дітей із нейтрофільним патерном (вміст нейтрофілів $\geq 5000$ клітин/мм ${ }^{3}$ ) (середній вік $-12,6 \pm 2,7$ року, частка хлопчиків - 64,3\%), до IV групи увішли 12 дітей 3 гіпергранулоцитарним патерном запальної відповіді (вміст еозинофілів крові $\geq 250$ клітин/мм ${ }^{3}$ та нейтрофілів $\geq 5000$ клітин/мм ${ }^{3}$ ) (середній вік $14,9 \pm 1,9$ року; частка хлопчиків - 58,3\%. За основними клінічними характеристиками групи спостереження були зіставлюваними.

Одержані результати дослідження аналізували 3 позицій біостатистики та клінічної епідеміології за допомогою комп'ютерних пакетів "Statistica7" StatSoft Inc. та Excel XP для Windows, різницю показників вважали статистично значимою за $\mathrm{p}<0,05.3$ позицій клінічної епідеміології визначали відносний ризик (ВР) та співвідношення шансів (СШ) розвитку певної події. Відбір та обстеження пацієнтів відповідали принципам біомедичної етики в педіатрії.

Iз метою встановлення особливостей запальних фенотипів бронхіальної астми нами проведено дослідження клінікоанамнестичних характеристик БА в дітей залежно від запальних паттернів периферичної крові.

Нами проаналізовано показники віку дебюту захворювання в дітей груп спостереження (табл. 1).

\section{Таблиця 1}

\section{Розподіл паціснтів, хворих на бронхіальну астму, залежно від віку} початку хвороби з врахуванням запального паттерну крові (\%)

\begin{tabular}{|l|c|c|c|}
\hline \multirow{2}{*}{ Клінічні групи } & \multicolumn{3}{|c|}{ Вік дебюту бронхіальної астми } \\
\cline { 2 - 4 } & До 3-х років & Від 3 до 6 років & Після 6 років \\
\hline I група (n=34) & 26,5 & 26,5 & 47,0 \\
\hline II група (n=60) & 28,3 & 20,0 & 51,7 \\
\hline III група (n=14) & 28,6 & 28,6 & 42,8 \\
\hline IV група (n=12) & 33,3 & 16,7 & 50 \\
\hline $\mathrm{p}$ & $>0,05$ & $>0,05$ & $>0,05$ \\
\hline
\end{tabular}

Оцінка дебюту захворювання в групах спостереження показала, що серед обстежених дітей відмічалася тенденція до переважання так званої «астми пізнього початку». Разом із тим удвічі переважала частка 
хворих із дебютом БА у ранньому віці порівняно з дошкільним віком $(33,3 \%$ проти $16,7 \%, \mathrm{p}<0,05)$ серед представників IV групи.

Ураховуючи суперечливі дані щодо асоціації особливостей вигодовування, проявів атопії на першому році життя та можливості розвитку бронхіальної астми нами проаналізовано дані показники (рис. 1). Вірогідної різниці щодо особливостей вигодовування на першому році життя та проявів атопії у групах спостереження не виявлено. Проте встановлено, що серед хворих 3 гіпергранулоцитарним паттерном запалення (IV група) кожна п'ята дитина вигодовувалась штучними сумішами, причому серед пацієнтів II групи таких було менше 5,0\%, а в половини хворих IV групи траплялися шкірні прояви атопії в грудному віці. Результати досліджень асоціації штучного вигодовування, наявності атопії в ранньому віці та розвитку бронхіальної астми наразі досить неоднозначні, оскільки остаточно ці дані не доведені.

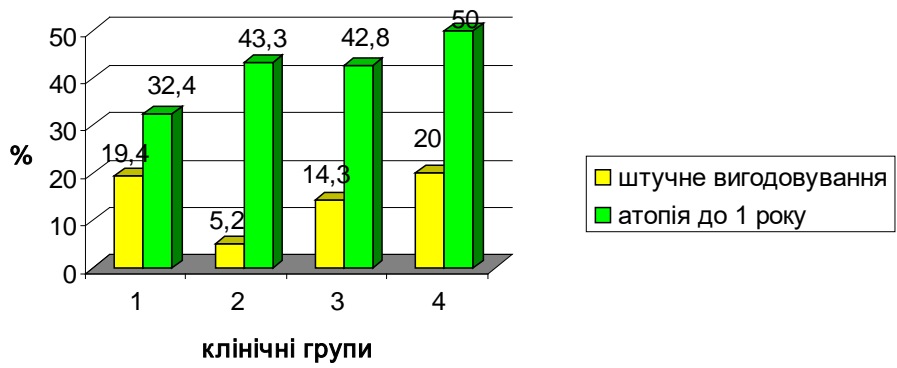

Рис. 1. Частота ресстрації штучного вигодовування та проявів атопії на 1-му році життя у дітей груп спостереження

Беручи до уваги те, що одним із факторів тяжчого перебігу БА у дітей $\epsilon$ підвищена маса тіла, проведено аналіз ступеня вгодованості за індексом маси тіла (IMT) пацієнтів груп порівняння (рис. 2). Так, встановлено вірогідно вищі показники ступеня вгодованості за IMT у пацієнтів IV групи порівняно до представників II та III клінічних груп.

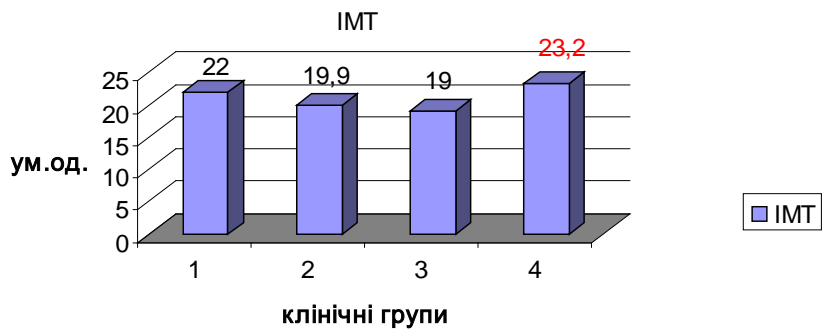

Рис. 2. Показники індексу маси тіла в дітей груп спостереження 
Ураховуючи генетичну детермінованість БА в дітей, проведено оцінку обтяженості сімейного анамнезу атопічними захворюваннями за даними генеалогічного індексу (ГІ). Зокрема, встановлено наявність вірогідних відмінностей щодо виразнішого ГI в дітей за гіпергранулоцитарного паттерну запалення крові порівняно із хворими 3 нейтрофільним фенотипом БА, а також відсутність відмінностей за даним індексом з представниками I та II клінічних груп (рис. 3).

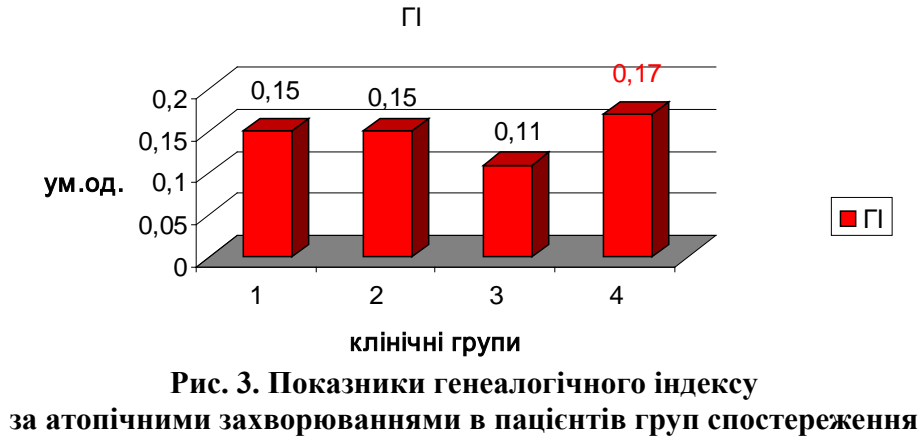

Порівнюючи дані анамнезу у клінічних групах, встановили, що сезонність проявів БА в осінньо-зимовий період року (66,7\% випадків) та провокація нападу астми за рахунок неспецифічних тригерних чинників $(83,4 \%$ спостережень) притаманні нейтрофільному фенотипу БА. Водночас загострення хвороби навесні реєстрували у 45,6\% хворих 3 еозинофільним фенотипом астми, $24 \%$ пацієнтів із гіпогранулоцитарним фенотипом запалення та у кожного третього хворого із гіпергранулоцитарним паттерном запалення крові. Специфічні тригерні стимули (харчові, інгаляційні, побутові алергени) викликали загострення астми у представників I та II клінічних груп у $39 \%$ та $50 \%$ випадків відповідно. Водночас в анамнезі хворих із гіпергранулоцитарним запальним паттерном крові тригерними чинниками загострення БА найчастіше виступали метеофактори (75\% спостережень).

Виходячи 3 виявлених анамнестичних особливостей, проведено оцінку тяжкості перебігу БА в дітей груп спостереження (табл.2). Встановлено, що персистувальний тяжкий перебіг БА реєструвався в переважної більшості хворих із гіпергранулоцитарним паттерном та вірогідно перевищував зареєстровані відповідні показники у пацієнтів I, II, III клінічних груп.

Детальна оцінка показників тяжкості перебігу БА (рис.4) продемонструвала, що в кожної четвертої дитини 3 гіпергранулоцитарним фенотипом БА відзначалися часті нічні симптоми захворювання понад 
1-3 рази/тиждень (25\% випадків), кожен третій пацієнт даної групи потребував застосування швидкодюючих бронходілятаторів в обсязі більше 4 доз на день, що свідчило про неконтрольованість астми. Неможливість втримання контролю у хворих 3 гіпергранулоцитарним фенотипом БА підтверджувалося підвищеною потребою у стаціонарному лікуванні (понад 3 рази/рік) пацієнтів даної групи.

Таблиця 2

Розподіл паціснтів, хворих на бронхіальну астму, залежно від тяжкості перебігу хвороби з врахуванням запального паттерну крові, (\%)

\begin{tabular}{|l|c|c|c|}
\hline \multirow{2}{*}{$\begin{array}{c}\text { Клінічні } \\
\text { групи }\end{array}$} & \multicolumn{3}{|c|}{ Персистувальний перебіг бронхіальної астми } \\
\cline { 2 - 4 } & легкий & \multicolumn{1}{|c|}{ середньотяжкий } & тяжкий \\
\hline I група & 17,6 & 38,2 & 44,2 \\
\hline II група & 11,7 & 50 & 38,3 \\
\hline III група & 21,4 & 35,7 & 42,9 \\
\hline IV група & - & 25 & 75 \\
\hline P I:II:IV & $<0,05$ & $>0,05$ & $<0,05$ \\
\hline
\end{tabular}

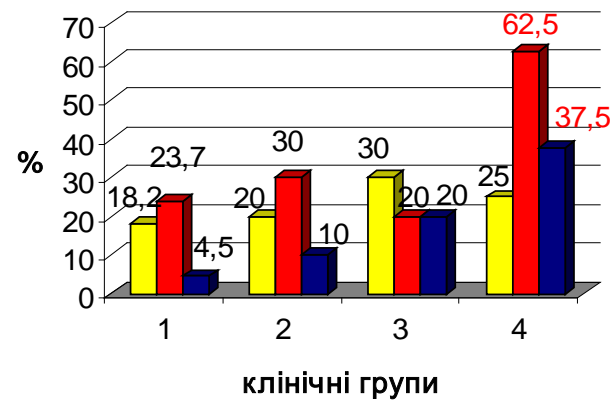

\begin{tabular}{|l}
$\square$ нічні симптоми> 1-3 \\
ночі/тижд \\
$\square$ частота госпіталізацій \\
$>3$ разів/рік \\
\\
частота застосування \\
бета-2-агоністів> 4 \\
доз/день
\end{tabular}

Рис. 4. Клінічні показники тяжкості бронхіальної астми в дітей груп спостереження

Водночас у пацієнтів із нейтрофільним фенотипом БА оцінка показників тяжкості перебігу астми продемонструвала вірогідне переважання частково контрольованого захворювання, оскільки у $30 \%$ випадків реєструвалися часті нічні симптоми хвороби, а кожна п'ята дитина потребувала застосування більше 4 доз сальбутамолу на добу та відчувала необхідність у повторних госпіталізаціях (понад 3 рази/рік) у зв'язку із загостренням захворювання.

Узагальнюючи наведене вище, відзначимо, що гіпергранулоцитарний фенотип БА асоціював із виразним ступенем вгодованості за показниками IMT, шкірними проявами атопії в ранньому віці, високими 
показниками генеалогічного індексу за атопічними захворюваннями в родині, впливом неспецифічних тригерних чинників, а також тяжким, неконтрольованим перебігом захворювання. Нейтрофільний запальний паттерн крові в дітей, хворих на БА, характеризувався низькими показниками генеалогічного індексу за атопією, загостреннями хвороби в осінньо-зимовий період року та переважним впливом неспецифічних тригерних чинників, а також частково контрольованим перебігом захворювання. Еозинофільний фенотип БА притаманний хворим із нормальними показниками IMT, загостренням у весняний період року за участі специфічних тригерних чинників, що узгоджується з обтяженим генеалогічним анамнезом за атопічними захворюваннями.

\section{2. Параклінічні особливості перебігу бронхіальної астми в дітей шкільного віку за різних запальних паттернів крові}

Ураховуючи численні суперечливі дані стосовно вибору оптимального маркеру запалення дихальних шляхів, нами, окрім визначення запальних паттернів крові, проведено аналіз цитологічного дослідження індукованого мокротиння, результати якого наведені у табл. 3 .

Таблиця 3

Цитологічний склад мукоспіну дітей клінічних груп порівняння $(\mathrm{M} \pm \mathrm{m})$

\begin{tabular}{|l|c|c|c|c|c|}
\hline \multirow{2}{*}{$\begin{array}{c}\text { Клінічні } \\
\text { групи }\end{array}$} & $\begin{array}{c}\text { Цозино- } \\
\text { філи }\end{array}$ & $\begin{array}{c}\text { Нейтро- } \\
\text { філи }\end{array}$ & $\begin{array}{c}\text { Лімфо- } \\
\text { цити }\end{array}$ & $\begin{array}{c}\text { Альвеолярні } \\
\text { макрофаги }\end{array}$ & $\begin{array}{c}\text { Злущений } \\
\text { епітелій }\end{array}$ \\
\hline I група & $11,2 \pm 4,2$ & $51,3 \pm 4,0$ & $10,3 \pm 2,3$ & $27,5 \pm 3,6$ & $46,4 \pm 3,9$ \\
\hline II група & $10,6 \pm 2,3$ & $49,9 \pm 3,5$ & $8,5 \pm 1,9$ & $30,6 \pm 3,4$ & $38,1 \pm 2,4$ \\
\hline III група & $12,3 \pm 3,4$ & $58,4 \pm 5,4$ & $13,3 \pm 5,2$ & $18,1 \pm 6,0$ & $38,1 \pm 6,7$ \\
\hline IV група & $15,1 \pm 9,6$ & $42,7 \pm 8,3$ & $9,2 \pm 4,0$ & $33,0 \pm 10,6$ & $34,6 \pm 6,8$ \\
\hline p & $>0,05$ & $>0,05$ & $>0,05$ & $>0,05$ & $>0,05$ \\
\hline
\end{tabular}

Виходячи 3 того, що в здорових дітей максимальний відносний вміст еозинофільних лейкоцитів у мокротинні не перевищує $2 \%$, а основними клітинами мокротиння є легеневі мононуклеари, частка котрих зазвичай становить 80-90\%, зазначено, що в обстежених дітей клінічних груп визначалося відносне зменшення пулу нормальних клітин захисту легень - альвеолярних макрофагів із одночасним зростанням частки клітин, які асоціюють із запальною реакцією бронхів при БА: лімфоцитів, еозинофільних та нейтрофільних гранулоцитів. 
Слід визнати, що результати розподілу пацієнтів за паттерном запальної відповіді у крові не завжди співпадали 3 показниками цитологічного складу харкотиння в дітей груп спостереження.

Попри відсутність вірогідних відмінностей за середніми показниками клітинного складу індукованого мокротиння дітей клінічних груп порівняння, встановлено, що виразніша нейтрофілія бронхіального секрету була притаманна представникам III клінічної групи.

Так, відсотковий вміст нейтрофілів більше $65 \%$ реєструвався у половини $(50 \%)$ дітей із нейтрофільним характером запального паттерну крові, тоді як у пацієнтів I,II, IV груп порівняння - лише у $14,3 \%\left(\mathrm{p}_{\varphi}<0,05\right)$, $24,4 \%\left(\mathrm{p}_{\varphi}<0,05\right)$ та $13,5 \%\left(\mathrm{p}_{\varphi}<0,05\right)$ випадків відповідно. Показники ризику реєстрації понад $65 \%$ нейтрофілів в індукованому харкотинні в дітей ,хворих на бронхіальну астму в асоціації з нейтрофільним запальним патерном крові порівняно до гіпогранулоцитарного патерну, дорівнювали: відносний ризик - 2,1 [95\% ДІ:1,2-3,5] при співвідношенні шансів 5,9 [95\% ДІ:3,0-11,9], а по відношенню до еозинофільного запального патерну крові: відносний ризик - 2,1 [95\% ДІ:1,3-3,7] при співвідношенні шансів - 6,4 [95\% ДI:3,2-12,8].

Водночас відмічено, що підвищений вміст альвеолярних макрофагів (більше 34\%) траплявся в понад третини (37,5\%) школярів iз гіпергранулоцитарним запальним паттерном крові, проте в осіб із еозинофільним фенотипом БА - лише у $8,4 \%$ пацієнтів $(\mathrm{P} \varphi<0,05)$.

Поряд зі цим встановлена тенденція до збільшення кількості злущеного епітелію в мокротинні дітей із гіпогранулоцитарним варіантом запалення крові, що, за даними літератури, є маркером активності пошкодження слизової оболонки бронхів внаслідок їх запалення. Зокрема, вміст епітелію більше $46 \%$ у дітей I групи реєструвався у $52,4 \%$ пацієнтів, а у II, III, IV групах порівняння - лише у $24,4 \% \quad(p \varphi<0,05), \quad 33,4 \% \quad(p \varphi>0,05) \quad$ та $25 \% \quad(p \varphi<0,05) \quad$ випадків відповідно.

Таким чином, у дітей, хворих на БА, за нейтрофільного запального паттерну крові трапляється виразніше пошкодження епітеліального шару дихальних шляхів внаслідок їх нейтрофільно-макрофагальнолімфоцитарного запалення, а гіперганулоцитарний фенотип астми характеризується еозинофільно-лімфоцитарно-макрофагальним варіантом запальної відповіді бронхів.

Враховуючи недостатню інформативність та суперечливість даних різних досліджень стосовно виразності шкірної чутливості до алергенів у дітей, хворих на БА за різних запальних паттернів крові, проведено комплексне алергологічне обстеження пацієнтів, яке передбачало визначення шкірної чутливості негайного типу до основних груп небактеріальних алергенів (епідермальних, пилкових, харчових). 
Установлено, що виразна чутливість до побутових алергенів відзначалась у хворих II, III та IV груп, показники якої вірогідно перевищували результати вказаних проб у пацієнтів із гіпогранулоцитарним паттерном крові (табл. 4).

Таблиця 4

Показники шкірної гіперчутливості до небактеріальних алергенів у дітей груп спостереження, мм

\begin{tabular}{|l|c|c|c|}
\hline \multirow{2}{*}{$\begin{array}{c}\text { Клінічні } \\
\text { групи }\end{array}$} & \multicolumn{3}{|c|}{ Розмір папули шкірної реакції, мм } \\
\cline { 2 - 4 } & побутові & епідермальні & пилкові \\
\hline I група & $13,7 \pm 1,4$ & $13,7 \pm 1,5$ & $8,4 \pm 1,9$ \\
\hline II група & $17,8 \pm 1,0$ & $13,9 \pm 0,8$ & $10,6 \pm 1,2$ \\
\hline III група & $20,3 \pm 2,7$ & $13,7 \pm 1,2$ & $9,2 \pm 1,7$ \\
\hline IV група & $19,6 \pm 2,1$ & $22,6 \pm 7,2$ & $17,0 \pm 2,7$ \\
\hline P & I:II,III,IV $<0,05$ & II:IV $<0,05$ & I,III:IV $<0,05$ \\
\hline
\end{tabular}

Водночас найвищими виявилися показники шкірної гіперчутливості до небактеріальних алергенів у дітей, хворих на БА із гіпергранулоцитарним запальним паттерном крові, оскільки за розмірами папули шкірної реакції на побутові алергени вони вірогідно перевищували результати пацієнтів I групи, за чутливістю до епідермальних алергенів - були вірогідно вищими за показники хворих із еозинофільним фенотипом БА, а за результатами вивчення шкірної гіперчутливості до пилкових алергенів - вірогідно виразнішими за відповідні результати в пацієнтів із гіпогранулоцитарним та нейтрофільним фенотипами БА.

Узагальнючи наведені вище результати параклінічних досліджень дітей, хворих на бронхіальну астму, можна припустити, що для нейтрофільного паттерну запалення крові притаманними $\epsilon$ виразніше пошкодження епітеліального шару дихальних шляхів внаслідок їх нейтрофільно-макрофагально-лімфоцитарного запалення, помірно виражена шкірна гіперчутливість до епідермальних та пилкових алергенів та виразніша - до побутових алергенів, що в цілому співпадало $з$ даними літератури. Еозинофільний паттерн запалення крові в дітей, хворих на БА, асоціював із позитивними шкірними тестами із небактеріальними алергенами та еозинофільномакрофагально-нейтрофільний варіант запалення дихальних шляхів, що частково узгоджується 3 даними наукових досліджень різних авторів [9]. Для гіпогранулоцитарного фенотипу БА притаманні низькі показники шкірної чутливості до небактеральних алергенів та змішаний варіант запалення бронхів за наявності маркеру активного пошкодження слизової оболонки - злущеного епітелію. 
Водночас найвиразніше запалення дихальних шляхів із переважно еозинофільно-лімфоцитарно-макрофагальним варіантом запальної відповіді бронхів та різко позитивними шкірними тестами із небактеріальними алергенами встановлено в пацієнтів із гіпергранулоцитарним запальним паттерном крові.

\section{3. Діагностична цінність результатів комплексного обстеження дітей за різних фенотипів бронхіальної астми в дітей}

У табл. 5 наведені показники діагностичної цінності клінікопараклінічних маркерів та показники ризику щодо верифікації несприятливого перебігу БА у дітей за наявності гіпергранулоцитарного запального паттерну крові.

Таблиця 5

Показники ризику несприятливого перебігу БА

за наявності гіпергранулоцитарного запального паттерну крові у зіставленні з еозинофільною астмою у дітей

\begin{tabular}{|c|c|c|c|}
\hline \multirow[t]{2}{*}{ Показники } & \multicolumn{3}{|c|}{$\begin{array}{c}\text { Показники ризику несприятливого } \\
\text { перебігу захворювання }\end{array}$} \\
\hline & $\mathbf{A P}, \%$ & ВР (95\% ДІ) & СШ (95\% ДІ) \\
\hline Тяжкий перебіг БА & 36,7 & $1,9(1,3-2,8)$ & $4,8(2,6-8,8)$ \\
\hline $\begin{array}{l}\text { Застосування } \beta 2 \text {-агоністів } \\
\text { понад } 4 \text { доз/день }\end{array}$ & 27,5 & $3,7(2,9-4,7)$ & $5,4(2,5-11,6)$ \\
\hline $\begin{array}{l}\text { Частота госпіталізацій } \\
\text { понад } 3 \text { рази/рік }\end{array}$ & 32,5 & $2,1(1,5-2,8)$ & $3,9(2,1-7,0)$ \\
\hline Нічні симптоми > 1-3 ночі/тижд & 5,0 & $1,2(0,9-1,7)$ & $1,3(0,7-2,6)$ \\
\hline
\end{tabular}

Аналіз наведених даних показав, що у верифікації несприятливого перебігу БА високе інформативне та діагностичне значення мало визначення запальних паттернів крові - просте та доступне дослідженням в клінічній практиці.

Встановлення ознак гіпергранулоцитарного фенотипу хвороби в зіставленні 3 еозинофільною астмою, асоціювало із високими показниками ризику розвитку неконтрольованої або частково контрольованої астми, оскільки значна частка таких пацієнтів потребували частого застосування швидкодіючих $\beta 2$-агоністів короткої дії (в обсязі понад 4 дози/день), що також підтверджувалося підвищеною потребою у стаціонарному лікуванні (понад 3 рази/рік).

Таким чином, оцінка діагностичної значущості показників комплексного обстеження дітей залежно від запальних паттернів крові дозволила вважати, що визначення запальних фенотипів можна використовувати для 
виявлення несприятливого перебігу БА і обгрунтування індивідуального вибору лікувально-профілактичних заходів.

\section{ВИСНОВКИ}

Гіпергранулоцитарний фенотип БА асоціював із вищими показниками генеалогічного індексу за атопічними захворюваннями в родині $(0,17 \pm 0,02$ ум.од.) порівняно із хворими на БА із нейтрофільним паттерном крові, в яких ГІ дорівнював $0,11 \pm 0,01$ ум.од. ( $<0,05)$, що свідчило про вагомішу генетичну детермінованість захворювання за наявності гіпергранулоцитарного фенотипу БА.

На підставі аналізу клінічних даних встановлено, що тяжкий перебіг захворювання практично вдвічі частіше реєструвався у хворих із гіпергранулоцитарним паттерном крові, що почасти мав ознаки неконтрольованого або частково контрольованого перебігу, за якого виникали часті нічні симптоми, які потребували застосування $\beta 2$-агоністів понад 4 доз/день, що узгоджується даними літератури.

Показано, що наявність гіпергранулоцитарного запального патерну крові асоціювала із найвиразнішими показниками ремоделінгу дихальних шляхів за участі еозинофільно-нейтрофільно-макрофагального запалення. У пацієнтів із нейтрофільним запальним патерном крові пошкодження епітеліального шару дихальних шляхів виникало внаслідок їх нейтрофільно-макрофагально-лімфоцитарного запалення а шанси реєстрації понад 65\% нейтрофілів в індукованому харкотинні порівняно з гіпогранулоцитарним патерном зростали у 5,9 раз.

\section{АНОТАЦІЯ}

Проведення комплексного клінічно-параклінічного обстеження 120 дітей, хворих на бронхіальну астму, дозволило встановити, що гіпергранулоцитарний фенотип асоціювали зі шкірними проявами атопії в ранньому віці, високими показниками генеалогічного індексу за атопічними захворюваннями, тяжким неконтрольованим перебігом захворювання. Шанси втрати контролю за наявності гіпергранулоцитарного запального патерну крові підвищувались у 3,8 разу. Показано, що наявність гіпергранулоцитарного запального патерну крові асоціювала із найвиразнішими показниками ремоделінгу дихальних шляхів за участі еозинофільно-нейтрофільно-макрофагального запалення. У пацієнтів із нейтрофільним запальним патерном крові пошкодження епітеліального шару дихальних шляхів виникало внаслідок їх нейтрофільно-макрофагально-лімфоцитарного запалення а шанси реєстрації понад 65\% нейтрофілів в індукованому харкотинні порівняно до гіпогранулоцитарного патерну зростали у 5,9 раз. У хворих із еозинофільним патерном крові пошкодження слизової оболонки бронхів траплялося за 
участі еозинофільно-макрофагально-лімфоцитарного механізму, що зумовлює ефективність стандартної протизапальної терапії.

\section{ЛITЕРАТУРА}

1. Backer V., Stensen L., Sverrild A., et al. Objective confirmation of asthma diagnosis improves medication adherence. J Asthma. 2018. Vol. 55(11). P. 1262-1268.

2. Benedictis D., Bush A. Asthma in adolescence: Is there any news? Pediatrics Pulmonology. 2017. Vol. 52(1). P. 129-138.

3. Borak J., Lefkowitz R. Y. Bronchial hyperresponsiveness. Occupational Medicine. 2016. Vol. 66. P. 95-105.

4. Castro-Rodriguez J. A. The Asthma Predictive Index: early diagnosis of asthma. Curr Opin Allergy Clin Immunol. 2011. Vol. 11(3).P. 157-61.

5. Chen Q., Zhong X., Acosta L., et al. Allergic sensitization patterns identified through latent class analysis among children with and without asthma. Ann Allergy Asthma Immunol. 2016. Vol. 116(3). P. 212.

6. Cockcroft D.W. Methacholine challenge. PD20 versus PC20. Ann Am Thorac Soc. 2015. Vol. 12. P. 291-292.

7. Coşkun O., Ercan N., Bostanci I. Peripheral blood inflammatory patterns in the control levels of asthma in children. J Asthma. 2019. Vol. 5. P. $1-15$.

8. Durrant M.D., Metzger D.W. Emerging roles of T helper subsets in the pathogenesis of asthma"Immunological Investigations. 2010. Vol. 39(4-5). P. 526-549.

9. Gibson P. Inflammatory phenotypes in adult asthma: clinical applications. The Clinical Respiratory Journal. 2009. Vol. 3. P.198-206.

10. Hastie A.T., Steele C., Dunaway C.W., et al. Complex association patterns for inflammatory mediators in induced sputum from subjects with asthma. Clin Exp Allergy. 2018. Vol. (7). P. 787-797.

11. Helen K. Reddel, J. Mark Fitz Gerald, Eric D. Bateman GINA 2019: a fundamental change in asthma management . European Respiratory Journal. 2019. Vol. 53(6). P. 1901-1946.

12. Kooijman M.N., van Meel E.R., Steegers E., et al. Fetal umbilical, cerebral and pulmonary blood flow patterns in relation to lung function and asthma in childhood. Pediatr Allergy Immunol. 2019. Vol. 30(4). P. 443-450.

13. Kim S., Lee C.H., Jin K.N., Cho S.H., Kang H.R. Severe asthma phenotypes classified by site of airway involvement and remodeling via chest CT scan. J Investig Allergol Clin Immunol. 2018. Vol. 28(5). P. 312-320.

14. Nadif R., Siroux V., Boudier A., et al. Blood granulocyte patterns as predictors of asthma phenotypes in adults from the EGEA study. Eur Respir J. 2016. Vol. 48(4). P. 1040-1051. 
15. Ortega H., Llanos J.P., Lafeuille M.H., et al. Effects of systemic corticosteroids on blood eosinophil counts in asthma: real-world data. J Asthma. 2019. Vol. 56(8). P. 808-815.

16. Persson C. Primary lysis of eosinophils in severe desquamative asthma Clin. Exper. Allergy. 2014.Vol. 44( 2). P.173-183.

17. Pirogov A.B., Gassan D.A., Zinov'ev S.S., et al. Destruction of the bronchial epithelium in patients with severe asthma according to different patterns of inflammation and cold airway hyperresponsiveness. Ter Arkh. 2019. Vol. 91(3). P. 31-35.

18. Rakowski E., Zhao S., Liu M., et al. Variability of blood eosinophils in patients in a clinic for severe asthma. Clin Exp Allergy. 2019. Vol. 49(2). P. $163-170$

19. Teague W.G., Lawrence M.G., Shirley D.T., et al. Lung lavage granulocyte patterns and clinical phenotypes in children with severe, therapy-resistant asthma. J Allergy Clin Immunol Pract. 2019. Vol. 7(6). P. 1803-1812.

Information about authors: Tarnavska S. I., Candidate of Medical Sciences, Associate Professor at the Department of Pediatrics and Children Infectious Diseases HSEEU "Bukovinian State Medical University”

2, Teatralna sq., Chernivtsi, 58002, Ukraine Shahova O. O.,

Candidate of Medical Sciences, Assistant of the Department of Pediatrics and Children Infectious Diseases HSEEU "Bukovinian State Medical University" 2, Teatralna sq., Chernivtsi, 58002, Ukraine 